This is the author's final, peer-reviewed manuscript as accepted for publication. The publisher-formatted version may be available through the publisher's web site or your institution's library.

\title{
Words, borders, herds: postsocialist English and nationalist language identities in Mongolia
}

Phillip Marzluf

\section{How to cite this manuscript}

If you make reference to this version of the manuscript, use the following information:

Marzluf, P. (2012). Words, borders, herds: Postsocialist English and nationalist language identities in Mongolia. Retrieved from http://krex.ksu.edu

\section{Published Version Information}

Citation: Marzluf, P. (2012). Words, borders, herds: Post-socialist English and nationalist language identities in Mongolia. International Journal of the Sociology of Language, 2012(218), 195-216.

Digital Object Identifier (DOI): doi:10.1515/ijsl-2012-0064

Publisher's Link: http://dx.doi.org/10.1515/ijsl-2012-0064

This item was retrieved from the K-State Research Exchange (K-REx), the institutional repository of Kansas State University. K-REx is available at http://krex.ksu.edu 
Words, Borders, Herds:

Postsocialist English and Nationalist Language Identities in Mongolia 


\begin{abstract}
This article focuses on the sociolinguistics of globalism (Blommaert 2010) in Mongolia by examining two dominant language identities, postsocialist English and fundamentalist nationalist Mongolian. Postsocialist English, emerging as a vital part of the free-market capitalist economy in the 1990s, is analyzed in relationship with the now receding language identity of socialist Russian. Postsocialist English supports the values of transnational development, neoliberal economic policies, and post-industrial educational practices. The Mongolian fundamentalist nationalist language identity, on the other hand, responds to free-market globalism by appeals to the land and the traditional pastoral economy of herding. Yet, despite the fact that postsocialist English identifies Mongolians with anti-traditional and urban cultural and social values, the fundamentalist nationalist identity does not perceive of English as a threat; in fact, postsocialist English is used to mediate the anxiety that nationalist Mongolians feel towards China and their other new Asian trading partners. As free-market globalism continues to transform postsocialist Mongolia, including urban migration and the industrial mining of coal and other raw minerals, a sociolinguistics of globalism can continue to navigate the ways in which Mongolians craft their identity through language and, especially, the ways it relates to traditional notions of the land and the pastoral economy.
\end{abstract}

Keywords: Mongolia, globalism, postsocialism, nationalism, World English

Character Count: 61,922 (including empty spaces) 
Words, Borders, Herds: Postsocialist English and Nationalist Language Identities in Mongolia ${ }^{1}$

\section{Introduction}

Language identities are composed of ideologies, attitudes, folk beliefs and myths, narratives, and implicit and official language and literacy instruction policies that enable speakers to identify themselves with others. Speakers possess multiple language identities, some of which contradict with each other, or fade or emerge depending upon the historical, technological, political, and other social irruptions that mark the life experiences of individuals. Language identities are, needless to say, exceedingly complex, difficult to quantify, and unpredictable. Tabouret-Keller (1998) captures the dynamic complexity of identities, writing, “At any given time a person's identity is a heterogeneous set made up of all the names or identities, given to and taken up by her. But in a lifelong process, identity is endlessly created anew, according to very various social constraints (historical, institutional, economic, etc.), social interactions, encounters, and wishes that may happen to be very subjective and unique" (Tabouret-Keller 1998: 316). When compared to other forms of identities, language identities are less stable, comprised by a complex interplay of subjective and social, institutional factors. Exemplifying this complexity, Gee and Crawford (1998: 225-226) describe the multiple and possibly contradictory language identities swirling around the "master story" that people construct for themselves to account for their core, self identity. Depending upon the social or institutional context, language users adapt, blend, or bend identities together.

Language identities also allow people to dis-identify and exclude themselves from speakers of other languages (Schneider 2007: 27-28; Tabouret-Keller 1998: 316) or other varieties, dialects, or vernaculars of languages. Language identities, consequently, do the work of "language ideologies," which, according to Canagarajah (2000: 123), shape reality—or, to state 
this point in stronger terms - disallow adherents of a certain language ideology to see the world and their relationships with others in new and alternative ways. Language identities are always rhetorical and political acts, deeply embedded in other identity factors (especially religion and race/ethnicity) and particular social, cultural, historical, and technological contexts. Peirce (1995) outlines the consequences of these interactions between language and learners' social identities: I foreground the role of language as constitutive of and constituted by a language learner's social identity. It is through language that a person negotiates a sense of self within and across different sites at different points in time, and it is through language that a person gains access to — or is denied access to - powerful social networks that give learners the opportunities to speak. (Peirce 1995: 13)

Everyone is necessarily thrown into a language identity; no one speaker can claim the privilege of opting out of this particular type of identity, even though, certainly, people who participate in dominant language identities do ignore or naturalize the privileges that are conferred to them.

For the purposes of this article, one final important point regarding language identities is that they play a key role in the sociolinguistics of globalism. Due to the mobility of speakers and languages as well as the proliferation of new digital media, attempts to make generalizations about language grow even more complicated and unpredictable (Blommaert 2010: 4-5). The oftentimes violent juxtaposition of language identities, in which an "asymmetric" relationship of economic and cultural power forms between a dominant identity and one or more marginalized identities, not only redefines the identities in question but possibly redistributes what Peirce (1995: 13) refers to as "access to social networks" and disturbs the hierarchies, consequently, of those who are authorized to speak and write. The debate over the cultural and linguistic homogeneization of World English is one obvious example of analyzing language identities in 
terms of globalism. Phillipson (1992), Skutnabb-Kangas (2000), and others challenge the authenticity of the emerging language identity of global World English; instead, as Phillipson (1992: 43, 52-53, 55) argues strongly, global English replicates the conditions of colonialism, represents English as the desirable norm, and maintains the hierarchy between "developed" and “developing” nations. Concerned about the oversimplification of Phillipson's neo-colonial sociolinguistics and definitions of English as a "killer language," Pennycook (2007) and Blommaert (2010) argue for a more nuanced analysis to account for how speakers from marginalized and peripheral language communities use, borrow, adapt, and change a dominant language such as global English. In other words, the emergence of English may enable the production of new language identities that may transform English as well as "traditional" or other pre-existing identities.

In this article, my primary purpose is to extend the concept of language identities to the sociolinguistics of globalism in Mongolia. Using interview data, observational notes, websites, newspaper articles, and other sources, I describe two possible emerging language identities in globalizing Mongolia. The first is the dominant postsocialist English language identity that underwrites the discourse of supra-national development, adopts the North American and European ideographs of individuality and freedom, and takes for granted the economic common sense of the capitalist free market. This postsocialist English identity is relatively new, dating from the beginning of the 1990s, after the sudden demise of Soviet economic support, the legitimacy of socialist ideology, and a Russian-dominated urban ideology (Cohen 2005: 206; Kaplonski 2004: 37). Furthermore, postsocialist English is anti-traditional because of its association with free-market capitalism, the ideograph of individualism, and an economy that is based upon the privatization of property — a value that conflicts violently with a traditional 
Mongolian identity (Sarlagtay 2004). Yet, despite these core conflicts with "traditional" Mongolian values, I argue that English has quickly become a "common sense" language identity — the role of which is rarely questioned or challenged - precisely because it fulfills an "official" language function, replacing the now dormant socialist Russian identity. In short, I support Blommaert's (2010: 15-16) argument that globalization cannot be examined ahistorically_as an economic era that sprang out of nowhere in the 1990s. Even though we can clearly trace the emergence of English language training in the 1990s through transnational development agencies (e.g., the Peace Corps, the British Council, and the VSO), United States Christian missionary organizations, Mongolian national education policies, post-secondary institutions, and private language schools, we need to be aware of the preceding dominant language identities and institutions in order to make generalizations about the emergence of new dominant language identities.

In the following section, the alternative language identity that I describe is a fundamentalist nationalist language identity, one that has emerged alongside its dominant English counterpart in globalizing free-market Mongolia. It is necessary to foreground the discussion of this particular identity, though, with one admonishment: the fundamentalist nationalist identity is only one of many national and regional Mongolian language identities and should not be assumed to represent a dominant set of attitudes and beliefs. It is interesting for a sociolinguistics of globalism only in regards to how it positions itself against (or alongside) postsocialist English. This identity invokes traditional and rural rhetorical appeals of the Mongolian pastoral economy and the primordialism of land and ancestors. Bulag (1998: 6) lists these values as symbols of Mongolia purity: "virgin soil, animals, dung, milk, heart, mind, ancientness, [and] 'originalness." Kaplonski (2004: 19), similarly, describes how Mongolian 
identity is strongly attached to physical conceptions of the land, including homelands, pastures, valleys, and mountains. By invoking these symbols and values of tradition and primordialism, this language identity represents a fundamentalist position, one that, as Hardt and Negri (2000: 148-150) argue, provides an innovative response to exceedingly rapid global social, cultural, and economic changes. This fundamentalist position, however, does not reject the emergence of global English and, for the most part, takes issues of language for granted. As Cohen (2005: 210) suggests in an earlier study about English sociolinguistics in Mongolia, English can mediate Mongolian fundamentalist anxiety over the economic dominance of China and its new Asian trading partners - and does so quite literally in racist, anti-Chinese graffiti spray-painted in English. The fundamentalist nonchalance over the emergence of English may also exemplify Appadurai's (1994: 328) point that concerns over "Americanization” and cultural homogeneization can be overstated for countries that are much more anxious over the power of adjacent cultures.

Examining possible language identities in Mongolia is significant for the sociolinguistics of globalism because it expands upon sociolinguistic and transnational educational research that has focused primarily on how the language identities of former European colonies have resisted or accommodated post-colonial or neo-colonial periods. The educational, language, and literacy contexts of the so-called Soviet "second world" have been largely ignored (Steiner-Khamsi and Stolpe 2006: 6), and researchers in sociolinguistics have had to place transitioning and globalizing economies such as Mongolia into Khachru's “expanding circle”(see Cohen 2005: 205), a category that ignores the particular linguistic histories of postsocialist countries. When compared to the former Western colonies in Africa or India, postsocialist countries such as Mongolia possessed a different economic and cultural relationship with its "colonizing" state 
(i.e., the Soviet Union) and its "colonizing" reference language (i.e., Russian). Furthermore, Mongolia entered this transitional free-market economy phase at the same time as it adopted the legal and political discourses of globalism and international aid development. Ethnographic, sociological, economic, and historical research continues to trace the effects of this dramatic collision of socialist values with capitalist globalism in Mongolia. Among many changes since the cessation of Soviet assistance in 1990, there has been the de-urbanization of the countryside, especially in terms of institutional support for pastoral workers (Humphrey and Sneath 1999: 204-206; Rossabi 2005: 117-129; Sneath 2006: 141; Steiner-Khamsi and Stolpe 2006: 168-176), internal migration to the "urban periphery" of Ulaanbaatar (Gillet 2011; Sneath 2006: 158), and external migration for jobs in South Korea, Japan, Germany, and the United States (Rossabi 2005: 211); neoliberal privatization policies of the countryside are, according to several ethnographers, promoting the rise of herds to unsustainable levels and transforming conceptions of common pasture rights, placing "individualistic assumptions" upon "collectivist pastoralism" (Buell and Le 2006: 44-45); finally, Mongolia has become dependent upon international aid (Sneath 2006: 150) and has been a major borrower of North American and European educational concepts and pedagogical practices (Silova and Steiner-Khamsi 2008).

\section{Postsocialist English identity}

Despite the efforts of revolutionary societies to erase the previous dominant language and literacy identities and attitudes that underwrote now receding economic systems and value systems, traces of these identities do linger, constituting layers of emerging and receding identities and representing a "residuum" of earlier language practices or values that people may resort to when building and maintaining their identities (Blommaert 2010: 138, 186); although Steiner-Khamsi and Stolpe (2006: 24) use "residuum" to account for the socialist-era practices 
and attitudes that linger in postsocialist Mongolian classrooms, this concept can certainly by extended to identities themselves, reinforcing Blommaert's (2010) and Pennycook's (2007) arguments that new language identities are (re-)fashioned by the linguistic resources that language users have at hand. Similarly, Brandt (2001), in her historical examination of twentiethcentury literacy development in North America, describes an accumulative effect of previously dominant literacies upon emerging ones. Earlier literacy forms, such as the sacred, transformational roles ascribed to reading, are not simply jettisoned by digital-era literacy generations; indeed, these definitions of what constitutes a "literate person" — of crucial importance in the formation of a language identity_only become more complicated and saturated with previous literacy practices and attitudes.

In Mongolia, postsocialist English identity now obviously dominates second language instruction to such an extent that it makes the previous dominant second language identity, the Soviet-sponsored socialist Russian, difficult to recognize. In order to better examine the interconnections between English and previous or emerging identities, I first sketch out the socialist Russian identity that, beginning with the Mongolian communist revolution in the early 1920s, took several decades to consolidate itself as a dominant identity, one that, moreover, emerged because of the violent suppression and annihilation of pre-socialist political and religious institutions and the gradual rhetorical identification with the Soviet Union and its social, cultural, and economic institutions (Morozova 2009). ${ }^{2}$ From the 1950s through the 1980s, Russian language inundated the personal and professional lives of Mongolian elites and intellectuals and became the dominant first language in the contexts of politics, international relationships with other Soviet-supported states, and news media (Cohen 2005: 205-206; Kaplonski 2004: 42); as Cohen (2005: 204) relates, fluency in Russian was how elite Mongolians 
distinguished themselves as "literate." The most significant language reform policy, legislating the shift from Mongol bichig, the traditional Mongolian script, to Russian Cyrillic in the early 1940s, strengthened the Russian language identity while destroying the Buddhist culture that depended upon the traditional script (Morozova 2009: 106), making the learning of Russian easier and facilitating Mongolian intellectuals' education in the Soviet Union (Cohen 2005: $205){ }^{3}$ in the 1980 s, for example, approximately 6,000 Mongolian students studied in the Soviet Union and other Council for Mutual Economic Assistance (CMEA) states, a process, according to Steiner-Khamsi and Stolpe (2006: 70-71), of maintaining "cultural homogeneization in the socialist world"- - or, in other ways, of allowing this urban proletariat language identity to cross the borders of the CMEA states. Russian language training became a common part of the public school curriculum in the 1960s and the 1970s (Cohen 2005: 205), and Mongolian children began studying Russian in the third grade (UNESCO 1971: 8). Morozova (2009: 130) emphasizes the building of cultural institutions to "cast the national identity of the Mongols in a friendly attitude toward the Soviet people"; these included the construction of urban Soviet-supported cultural institutions in Ulaanbaatar in the 1940s and 1950s, such as the National Museum, the National Music-Drama Theatre, and the Union of Writers. ${ }^{4}$

To summarize, socialist Russian identity revealed the common sense of the Sovietsponsored socialism in Mongolia and was intimately tied to the credentialism of communist party membership (e.g., Morozova 2009: 108), mass literacy and alphabetization campaigns (Grivelet 2001), socialist internationalism, the re-definition of Mongolian ethnicity and nationalism along the lines of Soviet anthropology (Bulag 1998: 70-72), the re-articulation of Marxist ideology to accommodate the economic dominance of Mongolian nomadic pastoralism 
(Morozova 2009), and the urbanization and industrialization of Mongolian cities, rural infrastructure, and educational institutions.

In order to examine the sudden emergence of postsocialist English, interviews were conducted with three Mongolian language policy and language instruction experts: Choidon Zegiimaa, the President of the National Academy for Language Policy and a faculty member at the University of Humanities in Ulaanbaatar; Regsuren Bat-Erdene, the Director for Information, Monitoring and Evaluation in the Ministry of Education, Culture and Science; and Sodnom Khongorzul, a faculty member at the Mongolian National University. Although these interview participants do not represent all of the assumptions bound together with Mongolian, Russian, English, and other language identities, their experiences in language learning and teaching span the late-socialist and postsocialist periods in Mongolia, meaning that, according to Kaplonski (2004: 23-24), they carry with them the "national memory since the arrival of capitalism" as well as traces of the "official national memory." Before 1990, the year that marks the collapse of the socialist economy and the end of Soviet sponsorship, the interview participants espoused a strong Russian language identity. They undertook their post-secondary education in Russia, and their language beliefs and ways of seeing the world were mediated through Russian. Zegiimaa, for example, was a Russian language specialist before 1990, and she noted the importance of Russian for Mongolian intellectuals during the socialist period as well as the strong institutional support for Russian instruction in Mongolia and the implementation of standards and a rigorous and "scientific" language policy. According to Bat-Erdene, who also graduated from a Russian university, the interest in Russian actually intensified in the late 1980s, as Mongolian intellectuals observed political events in the Soviet Union through Russian media with a great deal of interest. Khongorzul learned English through the sponsorship of the Soviet Union and 
was one of the first Mongolian students to graduate from the American Studies program in the Institute for International Relations in Moscow.

The values invested in second language instruction are one way to begin differentiating the socialist Russian from the postsocialist English identities. ${ }^{5}$ Zegiimaa depicts Russian second language instruction in ways consistent with urbanizing and industrializing economies: central planning and authoritative institutional support mark the development and implementation of the Russian language curriculum as compared with the "chaotic" curriculum currently in place in post-secondary English language instruction. Along with government-supported training of Russian language teachers and the influx of Russian teachers from the Soviet Union (Cohen 2005: 205), the methods of instruction revealed the logic of industrializing economies, featuring teacher-centered classrooms and highly-structured curricula based on sequenced grammatical and syntactical items. When Zegiimaa expresses concern over the loss of a theory and structure for language training, she is tacitly acknowledging the pedagogical values of postsocialist English, which emphasizes an exposure to practical communication, the inclusion of popular culture, and such communicative-based methods as role plays and student collaboration. ${ }^{6}$ These pedagogical values constitute the "common sense" of a post-industrial economy—or, at least a language identity that is projecting itself on and fantasizing about a particular lifestyle and economic and social values (e.g., Tabouret-Keller 1998). Postsocialist English, in other words, values "immaterial labor" that produces and manipulates information and affect (Hardt and Negri 2004: 102, 108); it is a language marketed in a global economy in which capital no longer flows from obvious centers of power and key entrepreneurial criteria dominate, including worker flexibility, informal economies, and "competitive individualism" (Harvey 1989: 150-152, 171). Khongorzul's description of her teaching and curriculum design suggests this movement towards 
the post-industrialism in the Mongolian English classroom: instead of a focus on memorization that may mark the learning of Mongol bichig, for example, Khongorzul describes a picture textbook for primary school students that moves completely away from grammatical instruction, the use of Mongolian teenagers as English-speaking models, and the inclusion of rap music written by a Mongolian student. These types of methods and theory of instruction, according to Khongorzul, influence other aspects of foreign language teaching and the teaching of Mongolian language and other content subjects.

The commonsense of postsocialist English bases itself on the free market, an ideograph that frames thinking about education, language learning, employment, and many other sectors. English is represented as an unstoppable force, forcing language proficiency on to learners if they hope to be successful in life (Ulam 2011). Success, in this case, is defined by attending a post-secondary institution outside of Mongolia and participating in the free-market economy. One of the lead articles in Language Policy of Mongolia concludes with a flowchart in which the "Market-driven open economy" is emphasized as the very first stage in constructing a language policy (Chuluundorj and Zegiimaa 2006: 23). Extending this logic to the language identities, the free market then becomes, not surprisingly, the core value of postsocialist English, around which the fantasies about English and the English-speaking world and market values, such as globalism, neoliberalism, individualism, and entrepreneurialism, revolve; learning English, as others have argued, means identifying with the culture of consumption (see Pennycook 2007: 80). Steiner-Khamsi and Stolpe $(2006: 92,108)$ identify the free-market reforms that parallel the emergence of postsocialist English, including tuition-based higher education, a proliferation of private post-secondary institutions, decentralization of educational financing, the merging of schools and reduction of school staff, and the liberalization of textbook publication. 
Khongorzul's depiction of the job market for recent graduates with degrees in English acknowledges the neoliberal assumptions tied to a post-industrial labor market: although English has become an expectation and a hiring criterion for many jobs in Mongolia (see Grin 2001: 75) - a new characteristic for what it means to be "literate" for a middle-class MongolianKhongorzul underscores the problem of the lack of jobs and job security. Graduates require the entrepreneurial, flexible, individualist, and competitive values that English itself symbolizes.

Postsocialist English identity, obviously, does not rely upon "traditional" or constructedtraditional forms of national identity, which, as Sneath (2011: 34) explains, rely upon conceptions of "commonality and solidarity" of a people naturally and autochthonously arising from a well-defined geographical territory. Postsocialist English allows for its members to identify with an ideoscape (e.g., Sabloff 2011) that refers little to ethnic relationships and much more to values and beliefs that mark those of urban, middle-class, and, quite possibly, feminine identities. English, according to outsiders, provides a "shortcut to development" (Brooke 2005), in which "development" appears as an especially strong ideograph tying Mongolia to North American and Western European economic thinking. Reports that Mongolia will shift to Latin from the Cyrillic-based alphabet exaggerates these ideographic claims of development and its efficient connection to language (Brooke 2005). Although these claims regarding a preference for Latin alphabetization are more than likely overstated, what is interesting is the way in which this fantasy about English and the Latin alphabet differs in terms of the movement to Russian and Cyrillic during the middle of the twentieth century. Whereas the latter movement was indicative of urbanizing and industrializing economies, it was a nationalist ethnic identity project. The new Cyrillic script was based on the dialect of the dominant ethnic group of modern Mongolia, the Khalkh, and erased the traces of other possible ethnic Mongolian dialects 
(Grivelet 2001: 83). In short, middle twentieth-century Mongolia language policy, along with several other cultural, literary, and historical projects (Bulag 1998: 77), focused on crafting a Khalkh-centered ethnic and national identity that was, at the same time, amenable to the Soviet desire to promulgate patriotic nationalism, a patriotism that did not descend to more local conceptions of ethnicity, especially a "selfish" or "narrow-minded" ethnic nationalism that could contest the influence of the Soviet Union (Bulag 1998: 47). Again, the postsocialist English identity rarely, if at all, refers to ethnic or national identity; at the same time, as I will expand upon in the following section, the depiction of its relationship with Mongolian national or ethnic identities is a complicated issue. What is meant by the identity of the (English speaking) "New Mongol"? To what extent can we claim that Mongolians have lost their identity-either because of their Soviet socialist educational experience (Morozova 2009: 39) or, more recently, their identification with Western middle-class values and behaviors of consumption?

\section{Mongolian fundamentalist national language identity}

Words, borders, herds, with these three together

Who is rich? Mongolia is rich.

Words, borders, herds, with these three apart

Who is grieving? Mongolia is grieving. (Gantulga 2008)

Traditional and ruralist Mongolian belief systems are perhaps best represented by Zunduin Dorj's poem, “Hel, Hil, Mal”) ("Words, Borders, Herds”) which protests Russian livestock rustlers trespassing the northern frontier and unites Mongolian identity around land, language, and the pastoral economy of animal herding (see also Sarlagtay 2004). These ideographs represent what is held in common and the ways in which jenkhen ('authentic') traditionalist Mongolians view identity, ownership, and land rights differently than the private 
free-market articulated in the regime of global English. It is an identity authenticated by an appeal to the "common," what Hardt and Negri (2009: viii) define as "the common wealth of the material world" and "those results of social production that are necessary for social interaction and further production, such as knowledges, languages, codes, information, [and] affects." In postsocialist Mongolia, however, the cultural ideographs of the natural common - the land and pastoral herds - are threatened by the process of privatization and commodification described by Hardt and Negri (2004: 184-85) that redistributes power from the marginalized countryside to urban centers of global corporate power legitimated by global legal codes.

In a 2009 field study in Ulaanbaatar, one of my research questions was to ascertain the extent to which anxieties regarding an English-based globalism affected Mongolians’ representation of their national language. In short, how did the small Mongolian ultra-nationalist social movement, including the traditionalist "hel, hil, mal" language ideology as well as several neo-Nazi groups whose image tantalized an international audience in the summer of 2009 (e.g., Moxley 2009 ), address sociolinguistic concerns? I was especially interested in whether any language purity movements were attached to this nationalist movement and, if so, what they meant for the emergence of global English and English language instruction in Mongolia. Yet, unlike the politics that surround the Slovak status management policies (see Prendergast 2008) or the corpus language management in Albania (Dushku 1998: 369-70), among other examples, I uncovered few language purity movements or attention paid to invigorating the standards or status of Mongolian. Reports of vandalism to Chinese restaurant signs (Dayar Mongol 2009) may represent an attempt to exclude certain scripts from the public sphere in Ulaanbaatar, yet they do not suggest a sustained effort to enhance the status of Mongolian. Several of my interview participants stated concerns over the declining level of Mongolian, representing a 
narrative of literacy decline that is well known in North America and the United Kingdom (see Hourigan 1994), and pointed specifically to Mongolian journalism as the main source of concern. ${ }^{7}$ Although the proliferation of newspapers and Internet sites has coincided with the emergence of free market values and global English, the participants did not suggest a causal relationship between the demise of public Mongolian standards and the attention now paid to English instruction in the secondary and post-secondary curriculum.

The connection of language to the values of land and the pastoral is the most obviousand most important — way to contrast the fundamentalist nationalist language identity, as expressed in Dorj's "Hel, hil, mal," with postsocialist English. This attachment to land is not merely the expression of an abstract national patriotic feeling but a physical attachment to the land, a nutag ('homeland'), which connects Mongolians back to their "birthplace," "homeland," "pasture-land," or "Motherland" (Kaplonski 2004: 19). Unlike the urban privileging of middleclass postsocialist English, the fundamentalist identity still holds traces of the pastoral distrust of cities, which are regarded as a symptom of decline; furthermore, whereas the pastoral holds values of "authentic Mongolian culture, simplicity, and tradition" (Sneath 2006: 144) and still preserves a natural gendered logic (e.g., Benwell 2006: 128), the urban represents "the site of political power, foreign influences, chicanery and commerce" (Sneath 2006: 144). The "ultratraditionalist" movement articulates an even more extreme anti-urban position, advocating a nation-state constituted by nomadic khots - small state capitals of power that float around the Mongolian landscape (see Sarlagtay 2004: 329). Postsocialist English does not participate in this traditionalist construction of identity based upon a sense of common geography. These two emerging Mongolian language identities hold contradictory conceptions of land, identity, and economy - and, hence, drastically different values; yet, because the conceptual tools of Western- 
based sociolinguistics of globalism are ill equipped to look beyond the urban (see Phillipson 1992: 24), it becomes difficult to make generalizations about this contradictory relationship.

Nonetheless, a glance at the recent postsocialist past reveals the emergence of this fundamentalist traditionalist rhetorical movement. A raw nationalism emerged soon after the free market transition in the early 1990s, an expression of the "retrograde" or "narrow-minded" nationalism that the Soviets and Mongolian communists had paid particular attention to control and suppress (Bulag 1998: 47-48; Kaplonski 2004: 15-16). Undoubtedly, its most prominent impact upon Mongolian sociolinguistics was the exuberant return to Mongol bichig, an alphabetization campaign that exploited many of the same mass literacy strategies, such as learning circles and mass-produced primers, that had been set in place during the country-wide Cyrillic campaigns in the middle of the twentieth century. Grivelet (2001: 79-80) reports that approximately $60 \%$ of Mongolians were involved in learning the traditional script, though with varying degrees of success. The enthusiasm for Mongol bichig quickly diminished, and it was relegated to a ceremonial script taught in the public schools more for the purposes of cultural appreciation than for communicative purposes (Grivelet 2001: 87, 90). ${ }^{8}$ Yet, this alphabetization movement represents a nascent postsocialist nationalism that re-imagines an authentic Mongolian literary tradition.

In addition, Bulag (1998: 15) reports the occurrence of a temporary shift back to the countryside, an embrace of "rural power," and a public return to the traditional cultural rituals, such as the traditional Tsagaan sar ('New Year') and shamanistic rock worship, that were officially suppressed during the communist era. Early postsocialist nationalist movements, such as Khalkh Unen ('Khalkh Truth'), the House of Chinggis Khan (Kaplonski 84), and Mongol Ukhaan ('Mongolian Intelligence') (Bulag 1998: 165), involved themselves in the identity work 
of erasing the effects of Soviet colonialism and the contamination of Russian upon Mongolian thinking, titles, and concepts (Bulag 1998: 141) and to argue for a recovered—or newly constructed - authentic and pure Mongolian identity. To be a "real" Mongolian, to be jenkhen, was not to be Russian, Soviet, or "socialist." In the postsocialist era of free-market globalization, extremist nationalist groups continue these identity projects, although the lack of attention paid explicitly to language is striking. For example, the website of a Mongolian neo-Nazi group, Khukh Mongol (n.d.), includes a list of ten party principles, several of which focus on the protection of Mongolian heritage, culture, traditions, art, religion, and nationalist ideology yet without a specific mention of Mongolian language or script. Framed directly above the party principles, however, is a photograph of Khukh Mongol's notorious founder, Khon Khereediin B. Enkhbat, who is depicted writing in Mongol bichig. In this case, language hovers discretely in the background as a metonym of Mongolian heritage, tradition, and culture: it too deserves protection.

The history of language contact between Mongolian and a dominant external language, including Russian, Chinese, and Tibetan, indicates why ultra-nationalist language identities may attach less symbolic importance to the purity of Mongolian. Postsocialist English represents yet another dominant language, becoming such a part of the commonsense of Mongolian language identities that the Mongolian government, which had only a decade before debated whether to make Mongol bichig the official script, debated in 2004 to make English an official language in Mongolia (e.g., Brooke 2005). One of the interview participants, Bat-Erdene, was the most enthusiastic about an official English policy, one that made English the compulsory "second official language" for all documents published by the Mongolian government as well as for Mongolian companies that operated at the multinational level. Though Zegiimaa and Khongorzul 
were less enthusiastic about the attempts to make English official, they based their rejection of this policy on practical concerns regarding the lack of English fluency and linguistic resources rather than on concerns about national or linguistic identity.

The interviews indicate the common sense assumption that bilingualism or multilingualism is a historical linguistic fact in Mongolia; consequently, English, as the official external language of free-market capitalist globalism, fulfills a similar function to that of Russian as the official external language of Soviet internationalism. Similar to the history of Russian language contact, Mongolian experiences a "light" contact (Schneider 2007: 22) with English and absorbs and indigenizes many English words, especially in the discourses of technology, sports, and popular music. Its public scriptal environments, in Ulaanbaatar and border towns such as Sukhbaatar City, display a dizzying range of scripts, what Blommaert (2010: 11) describes as the "extreme mixedness" of language under the conditions of free-market global capitalism. For example, the facades of the socialist-era apartment blocks that constitute Ulaanbaatar's Third and Fourth Khuruulals ('Microdistricts'), enormous housing projects sponsored by the Soviet Union and constructed in the 1970s, now serve as advertising space, displaying, in at least three languages - Mongolian, English, and, less often, Russian — and three scripts - Cyrillic, Latin, and Mongol bichig - the services and products of a postmodern, global economy:

\section{Goyol Shop}

Korean Kid's Discount Shop

Happy Sansar Center

Karaoke

Game World 
Fast Food

Хороолол Бөөний Төв

Малайз Мебель

Мака Супэр Маркэт

Good Prince Supermarket

www.talktalkenglish.mn

Сувэнир Хоус

Гоо Сайхны Мэс Заслын “Урангоо” Эмнэлэг

Nivea Soft Та Нивео Софтой Заавал Хэрэглээрэй

The mixedness reveals itself in the transliteration of Mongolian words, such as Goyol ('beauty') and Sansar ('satellite'), into the Latin alphabet, and, vice versa, the appearance of English words in Cyrillic, including Сувэнир Хоус ('souvenir house') and, in an advertisement using two scripts, the name of the soap product, Nivea Soft, juxtaposed alongside its Cyrillic equivalent, Нивео Софт. In the list of signs above, Russian makes an appearance only once, Мебель ('furniture'), which is striking in a district of Ulaanbaatar that was once dominated by Russian language, even into the 1990s. Contrasting with the archetypal Russian socialist apartment blocks, these signs promote products and services of a vastly different economy, advertising retail shops, cosmetics, language education, gaming centers, and a plastic surgeon's clinic. Mongolia's new global trading partners are also frequently identified, including Malaysia ('Малайз') and Korea, countries that are now important countries for employment and education. The prosaically named bakery, Хороолол Бөөний Төв (the Khuruulal 'Bakery Center'), possibly displays a trace of the previous socialist economy; the "Good Prince 
Supermarket," finally, combines both English as well as an appeal to a pre-socialist traditionalism and aristocracy.

Mongolian national language identities accept the mixedness of these public environments as well as those of the newer digital media of television text-messaging programs, websites, personal blogs and social networking sites, and digital videos. Yet, without entering the debate initiated by Phillipson (1992), Pennycook (2007), and others regarding the homogenization or Americanization of the Mongolian public, it is important to note that the interview data and several articles from Language Policy of Mongolia do support the need for official, top-down regulation of public scripts and languages. Chuluundorj and Zegiimaa (2006: 23), stipulating that language policy originates with the free market, conclude that its final output is "Mongolian language identity and multilingual education"; in short, they imply the recognition of a complexity of language attitudes that may necessarily conflict with each other:

Mongolian society has to avoid a loss of its cultural and linguistic identity. We can see that appearances in advertisements and public service leaflets are changing: use of foreign languages in place names, public signs, and road signs become very common. The real problem is in our capacity to tolerate these changing appearances. (Chuluundorj and Zegiimaa 2006: 23)

The "real problem," then, is the ability of Mongolian language identities to "tolerate" and absorb this mixedness. Paradoxically, official governmental intervention is necessary to control the language use of the free market — what has been identified as the core value of contemporary Mongolian language policy as well as of postsocialist English-in order to protect Mongolian language identity from itself. 
A paradox, in terms of ultra-traditionalist and ruralist identities, is that linguistic mixedness is taken for granted, whereas Mongolian ultra-traditionalist anxieties regarding ethnic or genetic mixing constitute a large part of their rhetorical construction of identity. Who is truly Mongolian as opposed to who is an erliiz, or mixed or "contaminated" Mongolian does not only come down to language, simply because language in this case does not do a good enough job of testing the authenticity of Inner Mongolian or Buryat speakers who may have become too Chinese or Russian, respectively, in terms of genetics and cultural values. In Bulag's (1998: 80, 158-159) discussion of the folk ethnic theories that describe the signs for detecting genetic purity as well as the hidden, alien traits of the erliiz, language does appear once, in the language myth that erliiz children, regardless of where they grow up, will speak Mongolian with a Chinese accent. A YouTube clip (Dayar Mongol vs. Lundeejantsan 2007) promoting the activities of another prominent neo-Nazi group, Dayar Mongol, further presents these racist beliefs for determining authenticity. Z. Erdenebileg, the director of Dayar Mongol, points out the number of Mongolian national government representatives that he feels are erliiz or truly Chinese, basing his judgments on physiognomy and on an "ethnic" feeling that he possesses.

Although their pronouncements about language are far from consistent, ruralist and traditionalist fundamentalist identity positions perform a rhetoric of cultural defense that combines earlier, industrial-era protest media, such as graffiti and flyers, with the digital media of proto-informational globalism, including blogs, websites, and YouTube videos (e.g., Dayar Mongol 2009). These groups are fundamentalist, as defined by Hardt and Negri (2000: 146), because they represent an anti-modernist social movement; importantly, Hardt and Negri (2000: 146-147) warn us to "understand the various fundamentalisms not as the re-creation of a premodern world, but rather as a powerful refusal of the contemporary historical passage in 
course." These groups, therefore, are innovative, performing a response to globalism in which they construct literal and metaphorical boundaries (Žižek 2008: 102) and use fundamentalist images, symbols, and values of a constructed past (see Hardt and Negri 2000: 148-150). These fundamentalist rural language identities do not necessarily reject English, yet participate in a “constructed primordialism" (Appadurai 1994: 325), appealing to a constructed monoculture, a constructed ethnic homogeneity, and, henceforth, a constructed authenticity. A phenomenon that Appadurai (1994) points out is that these traditionalist identities contest little of the Americanization or Western homogenization of global capitalism, reserving their anxiety and contestation for China and their new economic Asian partners. Appadurai (1994: 328) writes, fittingly as far Mongolia's relationship with its much larger southern neighbor is concerned, "[F]or polities of smaller scale, there is always a fear of cultural absorption by polities of a larger scale, especially those that are nearby. One man's imagined community is another man's political prison." The fact that in Ulaanbaatar anti-Chinese and neo-Nazi Mongolian graffiti is oftentimes spray-painted in English or that anti-Chinese lyrics are shouted out in Americanstyled rap songs (e.g., 4 Züg n.d.) is a powerful reminder that crude traditionalist and nationalist messages can be expressed in terms of a "killer" language that does not itself participate in the ethnic or nationalist identity building. Or, another interpretation is possible. The violence of these messages may also be directed towards those who identify with postsocialist English, who have abandoned "traditional" conceptions of Mongolian identity for the ideographs of development, urbanism, and globalism. As Kaplonski (2004: 43) argues about the postsocialist English identity valued by the proto-informational economy, a Mongolian's English fluency or association with a multinational company may complicate her identity, challenging her claim to an "authentic" Mongolian identity. 


\section{Conclusion}

While analyzing the emergence since the early 1990s of a dominant postsocialist English identity in Mongolia, I have attempted to contribute to the sociolinguistics of globalism by demonstrating the need to attend closely to the linguistic and educational historical contexts that mark both the "traditional" past and the recent past. In order to examine the emergence of globalizing English in Mongolia, for example, researchers need to pay close attention to the previous dominant second language identity, socialist Russian, as well as other important language identities, such as the several formations of Mongolian nationalist language identity. I have chosen to analyze English as interrelating with a fundamentalist national language identity in order to emphasize how these identities perform important rhetorical work, manipulating symbols and images in order to create and maintain an identity, to argue for one's position in a globalizing economy, and to fight for access to linguistic and cultural power. To cite the Khukh Mongol website (n.d.) again, images of the Mongolian landscape are presented alongside the images of globalization: a photograph of industrial deforestation, passports, as well as three urban image events performed by the group, including a press conference and a protest march. The antithesis of images clashes pastoral values with anxieties over national ownership and citizenship; perhaps more interestingly is the homage to the Western-styled post-industrial press conference, in which Khukh Mongol leaders deliberately adopt the technological and rhetorical style of the non-traditionalist postsocialist English identity.

In contrast to commonsensical sociolinguistic generalizations that would place postsocialist English in conflict with fundamentalist nationalist Mongolian identities_-between the global/official and local/vernacular - I have tried to argue that, for the most part, little linguistic anxiety is expressed by those who hold these nationalist positions. Although public 
media in Mongolia acknowledges the hegemony of English as well the proliferation of English and the Latin script in the urban environment (e.g., Dogsmaa 2009), the role of English as the dominant language of free-market capitalism fits comfortably in pre-existing Mongolian language value systems, which do not privilege monolingualism. Moreover, different economic, cultural, and demographic anxieties persist between Mongolia and China and its other new Asian trading partners. The postsocialist English identity, in these cases, serves a useful mediating role to both help defuse and express these anxieties. Importantly, no contradiction is perceived between free-market capitalism sponsored by postsocialist English and the maintenance of a postsocialist "traditional” Mongolian language and identity. Both have quickly become commonplaces outside of which no alternatives can be imagined.

Finally, this examination of language identities in globalizing Mongolia emphasizes the importance of basing sociolinguistic generalizations about the affects of globalization on specific values of what constitutes cultural and linguistic power. In Mongolia, it is imperative to acknowledge the rich vocabulary that constitutes a rural and traditionalist Mongolian's sense of identity as physically connected to a sense of place. However, these pastoral values are currently being challenged by legal redefining of property, a tremendous influx of international capital in the mining sector, dramatic rural-to-urban internal migration, and an equally dramatic shift from a pastoral economy to an industrial-mining one based upon the export of coal, copper, and other raw minerals (e.g., Rendeiro 2010; Watts 2011). The land, in other words, as a common resource that serves as the basis of identity, may be under the threat of privatization and neo-liberal policies that are metonymically bound to globalizing English. The death of an Inner Mongolian herder activist in northern China in 2011, protesting against coal trucks driving on pasture lands, 
serves as a powerful reminder of the conflict between the pastoral and industrializing economies (see Jiang 2011).

Language, however, remains a viable resource of the common, in the sense that it is shaped and reproduced by all speakers, regardless of the hierarchies of power that are maintained by certain language identities. Despite these social hierarchies, Hardt and Negri (2004) emphasize the fact that marginalized identities participate powerfully in linguistic production:

$[\mathrm{T}]$ he subordinated are often the most creative agents of a linguistic community, developing new linguistic forms and mixtures and communicating them to the community as a whole. [...] In fact, the contradiction between linguistic hierarchies and linguistic production and commonality is what makes language today such a powerful site of conflict and resistance. (Hardt and Negri 2004: 132) Language, in other words, may become more powerful as an identity factor, resisting, redefining, or indigenizing the cultural and social values packaged together with postsocialist, globalizing English. As these traditional forms of Mongolian identification change, in terms of postsocialist urbanization and the privatization and industrialization of the countryside, future sociolinguistic inquiries will need to examine how language is defined by traditional social movements, in the ways they represent themselves, express their anxieties, and resist globalism. Additionally, sociolinguists will need to track to the extent in which Mongolian national language identities continue to accept global postsocialist English as a language of economic and political power, in which anxieties over the rising global power of their southern Asian neighbors can oftentimes be expressed.

\author{
Notes \\ ${ }^{1}$ A Kansas State University Small Research Grant helped support this research project. I also \\ acknowledge the contributions of the American Center for Mongolian Studies, Demchig
}


Enkhbaatar, Yembuu Batchuluun, Regsuren Bat-Erdene, Choidon Zegiimaa, Sodnom Khongorzul, as well as the anonymous IJSL reviewers. Thanks to Ganbaatar Tamir for translating the Mongolian ultra-nationalist materials and Serj Battsetseg for translating the corpus management conference speakers and Zunduin Dorj's poem, "Hel, Hil, Mal." ${ }^{2}$ Steiner-Khamsi and Stolpe (2006: 28-32) describe the dominant second languages and educational eras that predate twentieth-century socialist Mongolia.

${ }^{3}$ Morozova (2009) argues that the development of the urban proletariat socialist identity in Mongolia was not an easy and immediate process. For example, examining this gradual transformation through the lens of official literacy events, Morozova (2009: 108) describes how the public documents of identification and party certification were at first incomprehensible to pastoral herders.

${ }^{4}$ Russian has certainly not been erased in Mongolia, although strong Russian language identities are now peripheral. Hongorzul (personal communication) reports a resurgence of external Russian status planning, including advertisements enticing young Mongolians to learn Russian. In addition to this, Bat-Erdene (personal communication) claims that Russian still remains important because English materials are quickly translated into Russian. ${ }^{5}$ In practice, though, the distinction between socialist Russian and Postsocialist English second language classes may not be as extreme as I am depicting it here. Steiner-Khamsi and Stolpe (2006: 112-113, 117-118) reveal the Soviet pedagogical values that resurface in Mongolian pedagogical practices that have been imported from Western Europe and North America. ${ }^{6}$ Another point of concern for Zegiimaa (personal communication) is the loss of the Russian linguistic advantage that Mongolia held in the era of Soviet socialist internationalism. Mongolia, 
unable to boast of the same English levels and resources as its Asian partners in the current era of postsocialist globalism, no longer holds a competitive linguistic position.

${ }^{7}$ The Official Language Law, established in 2003 ("Mongolian National" 2003), as well as the Official Language Council of Mongolia, an agency of the Ministry of Education, Culture, and Science, represent two governmental-level responses to language legislation. Along with the Montsame News Agency and other educational institutions, the Official Language Council conducted a conference on the issues of translating and using foreign words for political, civic, and economic purposes (Dogsmaa 2009). More recently, the Official Language Council (2011) has published a list of standards for spelling both Mongolian and foreign loan words in the Cyrillic script. The appendix of "Foreign Words Translated into Mongolian" is revealing in that it indicates the official sanction of such loan words from American business and managerial discourse as бэстсэллэр ('bestseller’), брэнд ('brand'), and стресс ('stress’).

${ }^{8}$ Official legislation still impacts the use of Mongol bichig. A 2010 presidential decree, for example, calls for the use of Mongol bichig on all official diplomatic correspondence as well as on identification cards, birth and marriage certificates, and education diplomas ("Presidential decree" 2010).

\section{References}

Appadurai, Arjun. 1994. Disjuncture and difference in the global cultural economy. In Patrick Williams \& Laura Chrisman (eds.), Colonial discourse and post-colonial theory: $A$ reader, 324-339. New York: Columbia University Press.

Benwell, Ann Fenger. 2006. Facing gender challenges in post-socialist Mongolia. In Ole Bruun \& Li Narangoa (eds.), Mongols from country to city: Floating boundaries, pastoralism and city life in the Mongol lands, 110-139. Honolulu: University of Hawaii Press. 
Blommaert, Jan. 2010. The sociolinguistics of globalization. Cambridge: Cambridge University Press.

Brandt, Deborah. 2001. Literacy in American lives. Cambridge: Cambridge University Press. Brooke, James. 2005. For Mongolians, E Is for English, F Is for future. The New York Times. http://www.nytimes.com/2005/02/15/international/asia/15mongolia.html (accessed 8 November 2011).

Buell, Paul D. \& Nga Le. 2006. Globalization and Mongolia: Blessing or curse? In Henry G. Schwarz (ed.), Mongolian culture and society in the age of globalization: Proceedings of an international research conference, Western Washington University August 5 - 6, 2005, 27-66. Bellingham, WA: East Asian Studies Press.

Bulag, Uradyn E. 1998. Nationalism and hybridity in Mongolia. New York: Oxford University Press.

Canagarajah, A. Suresh. 2000. Negotiating ideologies through English. In Thomas Ricento (ed.), Ideology, politics, and language policies: Focus on English, 121-132. Amsterdam \& Philadelphia: John Benjamins.

Chuluundorj, B. \& Ch. Zegiimaa. 2006. Language policy in the era of globalization. In B. Shirnen \& U. Suvdantsetseg (eds.), Language policy of Mongolia, 19-23. Ulaanbaatar: National Academy for Language Policy.

Cohen, Roger. 2005. English in Mongolia. World Englishes 24(2). 203-216.

Dayar Mongol. 2009. http://www.youtube.com/watch?v=EjYTwY2g20A\&feature= youtube_gdata_player(accessed 8 November 2011).

Dayar Mongol vs. Lundeejantsan. 2007. http://www.youtube.com/watch?v=dUMt31FRq OU\&feature $=$ youtube_gdata_player $($ accessed 8 November 2011). 
Dogsmaa, D. 2009. Эх хэлний ядуурал үндэсний аюулгүй байдалд харанга дэлдэж байна. [Poverty in our native language threatens national security.] Dayarmongol.com. http://www.dayarmongol.com/index.php?option= com_content\&view=article\&id=4286 (accessed 10 November 2011).

Dushku, Silvana. 1998. English in Albania: Contact and convergence. World Englishes 17(3). 369-379.

4 Züg. n.d. БүY давар хужаа нараa. [Don’t overstep the limits you Chinks.] S. Batchimeg, F. Billé \& G. Delaplace (trans.). http://www.gregorydelaplace.com/images/docs/ zugdavaren.pdf (accessed 8 November 2011).

Gantulga, N. 2008. Зундуйн Дорж: Таван жил хэвтэрт байхдаа өөрийгөө л буруутгалаа. [Zunduin Dorj: I blamed only myself when lying in bed sick for five years.] Olloo.mn. http://www.olloo.mn/modules.php?name=News\&file= print\&sid=1143505 $($ accessed 8 November 2011).

Gee, James Paul \& Valerie M. Crawford. 1998. Two kinds of teenagers: Language, identity, and social class. In Donna E. Alvermann, Kathleen A. Hinchman, David W. Moore, Stephen F. Phelps, \& Diane R. Waff (eds.), Reconceptualizing the literacies in adolescents' lives (1st edn.), 225-246. Mahwah, NJ: Lawrence Erlbaum.

Gillet, Kit. 2011. Vast Mongolian shantytown now home to quarter of country's population. The Guardian. http://www.guardian.co.uk/world/2011/may/15/shantytown-home-quarter-ofmongolians (accessed 1 June 2011).

Grin, François. 2001. English as economic value: Facts and fallacies. World Englishes 20(1). 6578. 
Grivelet, Stéphane. 2001. Digraphia in Mongolia. International Journal of the Sociology of Language 2001(150). 75-93.

Hardt, Michael \& Antonio Negri. 2000. Empire. Cambridge, MA: Harvard University Press.

Hardt, Michael \& Antonio Negri. 2004. Multitude: War and democracy in the age of empire. New York: Penguin Press.

Hardt, Michael \& Antonio Negri. 2009. Commonwealth. Cambridge, MA: Belknap Press of Harvard University Press.

Harvey, David. 1989. The condition of postmodernity: An enquiry into the origins of cultural change. Oxford, UK: Blackwell.

Hourigan, Maureen M. 1994. Literacy as social exchange: Intersections of class, gender, and culture. Albany: State University of New York Press.

Humphrey, Caroline \& David Sneath. 1999. The end of nomadism? Society, state, and the environment in Inner Asia. Durham, N.C: Duke University Press.

Jiang, Steven. 2011. Activists: Inner Mongolia protests continue. CNN. http://edition.cnn.com/2011/WORLD/asiapcf/05/31/china.mongolia.protest/ (accessed 1 June 2011).

Kaplonski, Christopher. 2004. Truth, history and politics in Mongolia: The memory of heroes. London: Routledge.

Khukh Mongol. n.d. Хөх Монгол бүлгэм. [Blue Mongolian Group.] http://www.huhmongol.blogspot.com (accessed 1 June 2011).

Mongolian national law: Concerning the official language. 2003. Legal Information Center. http://www.legalinfo.mn/law/details/486?lawid=486 (accessed 11 October 2012). 
Morozova, Irina Y. 2009. Socialist revolutions in Asia: The social history of Mongolia in the 20th century. Oxford: Routledge.

Moxley, Mitch. 2009. The Neo-Nazis of Mongolia: Swastikas against China. Time.

http://www.time.com/time/magazine/article/0,9171,1910893,00.html (accessed 6 November 2011).

Official Language Council of Mongolia. 2011. Кирил бичгийн бичлэгийн стандарт тогтоох тухай. [The establishment of Cyrillic script writing standards.] http://www.mecs.gov.mn/data/mecs_laws/Education/Mongol\%20ugs.pdf (accessed 15 November 2011).

Peirce, Bonny Norton. 1995. Social identity, investment, and language learning. TESOL Quarterly 29(1). 9-31.

Pennycook, Alastair. 2007. Global Englishes and Transcultural flows. London: Routledge.

Phillipson, Robert. 1992. Linguistic imperialism. New York: Oxford University Press.

Prendergast, Catherine. 2008. Buying into English: Language and investment in the new capitalist world. Pittsburgh: University of Pittsburgh Press.

Presidential decree: measures to increase the use of the Mongolian script in official documents. 2010. Ministry of Education and Science. http://www.mecs.gov.mn/director-content-377316.mw (accessed 11 October 2012).

Rendeiro, Mark F. 2010. Mongolia's mining wealth is cause for concern. The Guardian. http://www.guardian.co.uk/commentisfree/2010/may/15/mongolia-mining-wealthconcern (accessed 30 May 2011).

Rossabi, Morris. 2005. Modern Mongolia: From khans to commissars to capitalists. Berkeley: University of California Press. 
Sabloff, Paula L. W. 2011. '-Scaping' Mongolia. In Paula L.W. Sabloff (ed.), Mapping

Mongolia: Situating Mongolia in the world from geologic time to the present, 16-33.

Philadelphia: University of Pennsylvania Press.

Sarlagtay, Mashbat O. 2004. Mongolia: Managing the transition from nomadic to settled culture. In Jim Rolfe (ed.), The Asia Pacific: A region in transition, 323-334. Honolulu: AsiaPacific Center for Security Studies. http://www.apcss.org/Publications/Edited\%20 Volumes/RegionalFinal\%20chapters/BOOKforwebsite.pdf (accessed 6 November 2011).

Schneider, Edgar W. 2007. Postcolonial English: Varieties around the world. Cambridge: Cambridge University Press.

Skutnabb-Kangas, Tove. 2000. Linguistic genocide in education, or worldwide diversity and human rights? Mahwah, N.J: Lawrence Erlbaum.

Silova, Iveta \& Gita Steiner-Khamsi. 2008. Introduction: Unwrapping the post-socialist education reform package. In Iveta Silova \& Gita Steiner-Khamsi (eds.), How NGOs react: Globalization and education reform in the Caucasus, Central Asia and Mongolia, 1-42. Bloomfield, CT: Kumarian Press.

Sneath, David. 2006. The rural and the urban in pastoral Mongolia. In Ole Bruun \& Li Narangoa (eds.), Mongols from country to city: Floating boundaries, pastoralism and city life in the Mongol lands, 140-161. Honolulu: University of Hawaii Press.

Sneath, David. 2011. Mapping and the headless state: Rethinking national populist concepts of Mongolia. In Paula L.W. Sabloff (ed.), Mapping Mongolia: Situating Mongolia in the world from geologic time to the present, 34-59. Philadelphia: University of Pennsylvania Press. 
Steiner-Khamsi, Gita \& Ines Stolpe. 2006. Educational import: Local encounters with global forces in Mongolia. New York: Palgrave Macmillan.

Tabouret-Keller, Andrée. 1998. Language and identity. In Florian Coulmas (ed.), The handbook of sociolinguistics (Blackwell handbooks in sociolinguistics 4), 315-326. Oxford \& Malden, MA: Blackwell.

Ulam, N. 2011. Рожэр Малколм Батбаяр: AHУ IELTS-ийн шалгалтад “Yes” гэж хэлж шуугиан тарьсан. [Roger Malcolm Batbayar: The United States says "Yes" to the IELTS exam.] Onoodor [Today]. C3.

UNESCO. 1971. Education in the Mongolian People's Republic. 1971. Bangkok: UNESCO.

Watts, Jonathan. 2011. Gobi mega-mine puts Mongolia on brink of world's greatest resource boom. The Guardian. http://www.guardian.co.uk/environment/2011/nov/07/gobi-megamine-mongolia (accessed 13 November 2011).

Žižek, Slavoj. 2008. Violence: Six sideways reflections. New York: Picador. 